\title{
EFFECT OF CASCADE ON THE FIFTH NYMPHAL INSTAR OF DESERT LOCUST Schistocerca gregaria (FORSKAL) \\ Mohamad, E. S. ${ }^{1}$; Th. A. Abdel - Fattah ${ }^{1}$; H. M. Sobhy. ${ }^{2}$ and W. Z. Azer ${ }^{2}$ \\ 1-Locust and Grasshoppers Department, Plant Protection Research Institute, Agric. Res. Center \\ 2-Natural Resources Department, Institute of African Research and Studies, Cairo University
}

\begin{abstract}
Laboratory studied were carried out in an attempt to disclose the effect of IGR (Cascade) on one day old of the $5^{\text {th }}$ nymphal instar of the desert locust, Schistocerca gregaria (Forskal) by feeding technique.

The chitinase activity was significant increased between Cascade and control after 2, 4 and 6 days after treatment. The protease activity was significant increased between Cascade and control after 2, 4 and 6 days after treatment. Cascade was decreased the Alkaline Phosphatase activity after 2, 4 and 6 days from treatment. Cascade was increased ALT and AST activity after 2, 4 and 6 days compared to control.

Keywords: Schistocerca gregaria, Flufenoxuron, Chitinase, Protease, Alkaline phosphatase, Transaminase Enymes.

\section{INRODUCTION}

The desert locust, Schistocerca gregaria (Forskal) (Acrididae: Orthoptera) is one of the most important insect pests, because of its polyphagous nature, attacks on a wide range of plants including agricultural crops. Control of locusts requires the availability of safe methods, such as ecological, biological, or integrated controls (Wang and Wang, 2007), and the use of IGR pesticides is such an approach because of their low toxicity. However, only a small number of IGRs have been tested against locusts in the field, mainly just a few chitin inhibitors and plant-derived pesticides. Studies have shown that juvenile hormone analogues have a significant effect on the breeding and fecundity of the adult oriental migratory locust (Roland and Uwe, 2004; Cheng et al., 2007).

The present work aims to study the effect of Cascade against the $5^{\text {th }}$ instar nymphs of $S$. gregaria under laboratory conditions. The biochemical effects of Cascade on Chitinase, Protease, Alkaline phosphatase, Transaminase enymes.
\end{abstract}

\section{MATERIALS AND METHODS}

\section{Experimental Insects:}

The stock colony of the desert locust, $S$. gregaria was maintained for several years at the Locust Research Division, Plant Protection Research Institute, Agricultural Research Center, Dokki, Cairo. The insects were reared 
and handled according to (Hunter-Jones, 1961). Fresh clover leaves Alexandranium trifolum Linnaeus were used for feeding the insects in winter and the leaves of leguminous plant, Sesbania aegyptiaca Webster, were introduced during summer.

2. Chemical under Tests:

\section{Insect Growth Regulator (Cascade):}

Chitin synthesis inhibitor: Cascade 10\% EC (Flufenoxuron) A technical concentrate $10 \%$ of Flufenoxuron. Its chemical name is :

1-\{4-(2-chloro- $\alpha, \alpha, \alpha$,-trifluoro-p-tolyloxy)-2-fluorophenyl\}-3-fluorophenyl \}-3(2,6 - difluorobenzoyl) urea.

3- Bioassays Studies and Treatment of Experimental Insects:

Both sexes of one-day old of the $5^{\text {th }}$ nymphal of $S$. gregaria during synthesis and deposition of the newly adult cuticle (Taha and El-Gammal 1990) were treated by feeding technique with Cascade as the following: Leaves of $A$. trifolum were dipped in 105.2 ppm of Cascade for two minutes intervals. Then leaves were air dried before being offered to the nymphs for feeding while the control used was offered leaves treated with distilled water. Three replicates of 20 nymphs were subjected to each of the treated leaves.

After feeding for $24 \mathrm{hr}$ on the treated leaves, the alive nymphs were transferred onto untreated leaves and left to feed for $24 \mathrm{hr}$, after that mortality counts were recorded.

\section{4- Collection of haemolymph:}

Since heat fixation technique proved by many authors to be an excellent one in preventing blood coagulation and preserving the form of haemocytes as they had in circulating blood, this technique was followed as described by (Amin, 1998).

5- Determination of chitinase activity:

According to Bade and Stinson (1981)

6- Determination of protease:

According to (Gatehouse et al., 1999)

7- Determination of alkaline phosphatase:

8 - Transaminase Determination:

According to Powell and Smith (1954).

According to Reitman and Frankle (1957).

9- Statistical Analysis:

All experiments were conducted in 5 replicates. Data are presented as means \pm SD. Data were subjected to analysis of variance (ANOVA), and Duncon's multiple range test to differentiate between the means at $P<0.05$, using SAS program (SAS, 1988).

\section{RESULTS AND DISCUSSION}

\section{1-Biochemical effects of Cascade on S. gregaria by feeding technique:}

The effects of bioinsecticides, Cascade with LC $_{50}$ values $105.2 \mathrm{ppm}$, after 2, 4 and 6 days after treatment, while control were treated with distilled water. 


\section{Determination of Chitinase Activity:}

Data in Table (1) showed that, the chitinase activity highly significant increased between Cascade 589, 1293 and 1851 after 2, 4 and 6 days after treatment. $\mu \mathrm{g} \mathrm{N}$-acetylglucoseamine (NAGA) $\times 10^{3} / \mathrm{min} / \mathrm{gm}$ fresh weight and control (463 and 344 .

Ecdysis is initiated by apolysis the process that separates epidermal cells from the old cuticle by molting fluid secretion and ecdysal membrane formation. The molting fluid contains proteases and chitinases, enzymes that digest the main constitution of the old endocuticle (Reynolds and Samuels, 1996). The insect growth regulator, diflubenzuron interferes with the development of the cuticle, to which insect skeletal muscle is attached. The effect of diflubenzuron on the ultra structure of the muscle attachment to the cuticle in larvae of Noctuidae Spodoptera littoralis (Boisd.) is described, and it is concluded that there is no digestion of the affected old cuticle, and no digestion of the tonofibrillae (microtubules passing through the pore canals and attached to the cuticulin layer) (Hegazy and Degheele, 1990). The fluctuation in the chitinase activity in the homogenated larvae was observed by many authors. Markedly increase in chitinase activity occurred when treated $4^{\text {th }}$ instar larvae of $S$. littoralis were treated with diflubenzuron (Farag, 2001). Chlorfluazuron caused a significant increase in chitinase activity of $S$. littoralis (Abdel-Aal, 2006). These results agree with Al-Shannaf et al. (2012) found that insect growth regulators (chlorfluazuron and pyriproxyfen) caused highly significant increases in the activity of chitinase enzyme $(130 \%$ times in larvae of American bollworm, Helicoverpa armigera (Hub.).

Table (1): The effect of Cascade on chitinase activity of the $5^{\text {th }}$ nymphal instar of $S$. gregaria, ( $\mu \mathrm{g} \mathrm{N}$-acetylglucoseamine (NAGA) $\times 10^{3}$ /min / gm fresh weight).

\begin{tabular}{|l|c|c|c|}
\hline & Cascade & Control & LSD \\
\hline Chitinase 2 days & 589 a & $463 \mathrm{c}$ & 18.35 \\
\hline Chitinase 4 days & $1293 \mathrm{a}$ & $344 \mathrm{c}$ & 95.85 \\
\hline Chitinase 6 days & $1851 \mathrm{a}$ & $326 \mathrm{c}$ & 40.60 \\
\hline
\end{tabular}

F: Measurement of distance between individual distributions.

Means with the same letter are not significantly different.

Means with the same letter are not significantly different and $a={ }^{\star \star \star \star}, b={ }^{\star \star \star}, c==^{\star \star}, d={ }^{\star}$

\section{Determination of protease activity:}

Data in Table (2) revealed that, the protease activity significant increased between Cascade 8.56, 12.9 and $15.22 \mu \mathrm{mol} / \mathrm{min} . / \mathrm{mg}$ protein after 2, 4 and 6 days after treatment and control 7.94 and $9.72 \mu \mathrm{mol} / \mathrm{min} . /$ $\mathrm{mg}$ protein.

This result agrees with those obtained by Bakr (1986) on $M$. domestica after feeding the two days old larvae $1 \mathrm{ppm}$ of Dimilin, BAY SIR 8514 and Altosid. These IGRs increased of the majority of the free amino acids. The feeding deterrence caused by azadirachtin was manifested by a severely reduced food intake resulting in diminished weight gain compared with controls. This is in general agreement with previous observations (Mordue and Blackwell, 1993). Trumm and Dorn (2000) reported that the 
reduction of food intake after the azadirachtin treatment was accompanied and probably caused by a prolonged retention of food in the crop and a strongly retarded passage through the midgut. The effects of azadirachtin on gut physiology have been mostly related to efficiency of diet conversion and inhibition of digestive enzymes (Koul et al., 1996). Timmins and Reynolds (1992) reported that Azadirachtin reduced growth of $M$. sexta larvae due to impaired protein digestion by inhibition of trypsin synthesis and/or secretion by midgut cells. Other hypothesis puts forward to explain this phenomenon: reduction in the haemolymph nutrient content, i.e. proteins, lipids and carbohydrates. The growth rate of insects is generally more closely correlated with nutrient content in the leaves. Also malformations of nymphs are seen and nymphs developed abnormal. Before nymphs moved slowly and had no appetite. (Mordue and Blackwell, 1993) attributed the direct toxicity and rapid mortality to the combined activities of antifeedancy and insect growth regulatory (IGR) effects.

Table (2): The effect of Cascade on protease activity of the $5^{\text {th }}$ nymphal instar of $S$. gregaria, ( $\mu \mathrm{mol} / \mathrm{min} . / \mathrm{mg}$ protein).

\begin{tabular}{|l|c|c|c|}
\hline & Cascade & Control & LSD \\
\hline Protease 2 days & $8.65 \mathrm{a}$ & $5.55 \mathrm{~b}$ & 1.23 \\
\hline Protease 4 days & $12.9 \mathrm{~b}$ & $7.94 \mathrm{c}$ & 2.12 \\
\hline Protease 6 days & $15.22 \mathrm{c}$ & $9.72 \mathrm{~d}$ & 0.41 \\
\hline
\end{tabular}

F:Measurement of distance between individual distributions.

Means with the same letter are not significantly different and $a={ }^{\star \star \star \star}, b={ }^{\star \star \star}, c={ }^{\star \star}, d={ }^{\star}$

Determination of alkaline phosphatase activity:

Results presented in Table (3) cleared that, the alkaline phosphatase (ALP) activity significant decreased between Cascade 5.09, 5.08 and 5.01 U after 2, 4 and 6 days after treatment and control.

These results agree with those obtained by (El- Sheikh, 2002), some IGRs reduced the activity of ALP, pyriproxyfen against Agrotis ipsilon (Huf.). Also (Assar et al., 2012) the tested Cyromazine (CSI) against $4^{\text {th }}$ larval instar of $C$. pipiens compound induced a significant decrease in the activity ALP as compared to the control

On the other hand, IGRs increased the activity of ALP in Musca domestica (Linn.) larvae (Assar et al., 2010). Also those obtained by Saha et al. (1986) using JHA and ecdysterone against Chrysocoris stolli (Wolf); Anan et al. (1993) using pyriproxyfen against Pectinophora gossypiella (Saunders) and Earias insulana (Boisduval); Mostafa (1993) using pyriproxyfen, Sokar (1995) using hexaflumuron and Abdel-Aal (2002) using pyriproxyfen against $S$. littoralis.

Acid and alkaline phosphatases have been shown to be associated with insect development, especially in relation to nutrition and egg maturation (Tsumuki and Kanehisa, 1984). Sridhara and Bhat (1963) stated that the increase or decrease of both phosphatase enzymes during development is reflected in increase or decrease in acid-soluble phosphorus content. 
Table (3): The effect of Cascade on ALP activity of the $5^{\text {th }}$ nymphal instar of $S$. gregaria, unit (U).

\begin{tabular}{|l|c|c|c|}
\hline & Cascade & Control & LSD \\
\hline ALP 2 days & $5.09 \mathrm{c}$ & $15.6 \mathrm{a}$ & 1.28 \\
\hline ALP 4 days & $5.08 \mathrm{c}$ & $16.03 \mathrm{a}$ & 2.32 \\
\hline ALP 6 days & $5.01 \mathrm{c}$ & $17.1 \mathrm{a}$ & 0.18 \\
\hline
\end{tabular}

F:Measurement of distance between individual distributions.

Means with the same letter are not significantly different and $a={ }^{\star \star \star *}, b={ }^{\star \star *}, c={ }^{\star *}, d={ }^{*}$

Determination of Transaminase enzymes ALT and AST activities:

Results given in Table (4 and 5) clarified the effect of Cascade on the activity of Alanine Aminotransferase (ALT) and aspartate aminotransferase (AST) of $5^{\text {th }}$ instar nymph. The obtained results revealed that Cascade significant increased ALT and AST activity after 2, 4 and 6 days compared with control.

The inhibitory effect of some IGR'S on the activity of AST and ALT on C. pipiens larvae was in accordance with those obtained by Saha et al. (1986) using THA against Chrysocoris stollii; Abdel- Hafez et al. (1988) using diflubenzuron and triflumuron against $S$. littoralis ; Ahmed et al. (1990) using chlorofluazuron against S. Littoralis; Sokar (1995) using hexaflumuron against S. littoralis; Abdel-Aal (2002) using chlorfluazuron ,flufenoxuron and pyriproxyfen against $S$. littoralis. EL-sheikh (2002) using pyriproxyfen against $A$. ipsilon and Assar et al. (2010) using consult and match against $M$. domestica. The stimuatory effect induced on the total AST and ALT by cryomazine.

Specific types of proteins are sythesized in the haemolymph from precursors of amino acids by enzymatic transformation reactions. Glutamic acid is formed by amino transfer from aspartic acid by AST or from alanine by ALT. It is probably a very significant enzymatic activity in the final stage of development (Gowda and Ramaiah, 1976).

Transaminase enzymes were considered as key enzymes in the formation of non essential amino acids, which is formed inside the body not taken from outside in metabolism of nitrogen waste and gluconeogensis (Mordue and Goldworthy, 1973). The same authors stated that the change in transaminase levels have been correlated with anabolism or catabolism of protein. Maintenance of the balanced "amino acid pool" in insects is the result of various biochemical reactions carried out by a group of enzymes called amino-transferases (Meister, 1957). In addition, Glbert (1967) reported that the level of ALT varies with the amount of synthesized protein. The amino transaminase alanine is one of the components of oxidative metabolism of proline, which is utilized during the initial periods of flights; it acts as a catalytic agent in the carbohydrate metabolism.

Azmi et al. (1998) stated that the transaminases (ALT and AST) enzymes help in the production of energy and serve as a strategic link between the carbohydrates and protein metabolism and are known to be altered during various physiological and pathological conditions. 
Table (4): The effect of Neem, Cascade and mixture on ALT activity of the $5^{\text {th }}$ nymphal instar of $S$. gregaria, (U/ gm body weight).

\begin{tabular}{|l|c|c|c|}
\hline & Cascade & Control & LSD \\
\hline ALT 2 days & $51 \mathrm{c}$ & $27 \mathrm{~d}$ & 7.55 \\
\hline ALT 4 days & $65 \mathrm{~b}$ & $43 \mathrm{~d}$ & 11.40 \\
\hline ALT 6 days & $77 \mathrm{~b}$ & $52 \mathrm{~d}$ & 4.80 \\
\hline
\end{tabular}

F: Measurement of distance between individual distributions.

Means with the same letter are not significantly different and $a={ }^{\star \star \star \star}, b={ }^{\star \star \star}, c={ }^{\star \star}, d={ }^{\star}$

Table (5): The effect of Neem, Cascade and mixture on AST activity of the $5^{\text {th }}$ nymphal instar of $S$. gregaria, (U/ gm body weight).

\begin{tabular}{|l|c|c|c|}
\hline & Cascade & Control & LSD \\
\hline AST 2 days & $348 \mathrm{c}$ & $156 \mathrm{~d}$ & 50.00 \\
\hline AST 4 days & $390 \mathrm{c}$ & $343 \mathrm{~d}$ & 26.41 \\
\hline AST 6 days & $435 \mathrm{c}$ & $415 \mathrm{~d}$ & 23.26 \\
\hline
\end{tabular}

F: Measurement of distance between individual distributions.

Means with the same letter are not significantly different and $a={ }^{\star \star \star \star}, b={ }^{\star \star \star}, c={ }^{\star \star}, d={ }^{\star}$

\section{REFERENCES}

Abdel-Aal, A. E. (2002). Effect of some insect growth regulators on certain biological, biochemical and histopathological aspects of the cotton leafworm, Spodoptera littoralis (Bosid.) (Lepidoptera: Noctuidae) Ph. D. Thesis, Fac. Sci., Cairo Univ.

Abdel-Aal A. E. (2006). Effect of chlorfluazuron, nuclear polyhydrosis virus (SLNP) and Bacillus thuringiensis on some biological and enzyme activity of cotton leafworm, Spodoptera littoralis (Boisd.). Bull. Ent. Soc., Cairo Univ. Egyp., 22: 99-107.

Abdel-Hafez, M. M.; Shaaban, M. M.; EL-Malla, M. A.; Farag, M. and AbdelKawy, A. M. (1988). Effect of insect growth regulators on the activity of transaminases with reference to protein and amino acids in Egyptian cotton leafworm, Spodoptera littoralis (Boisd) .Minia J. Agric. Res. Dev., 10: 1357-1372.

Ahmed, Y. M.; Mostafa, A. M. and Shoukry, A. (1990). Effect of chlorfluzuron on transaminases activities in the larvae and pupae of Spodoptera littoralis. Rijksuniver. Gent., 55 (2b): 621-627.

Al-shannaf, H. M.; Mead, H. M. and Sabry, A. H. (2012). Toxic and biochemical effects of some bioinsecticides and IGRs on american bollworm, Helicoverpa armigera (hüb.) (Noctuidae: Lepidoptera) in cotton fields. J. Biofertil. Biopestic., 3 (1): 1-6.

Amin, T. R. (1998). Biochemical and physiological studies of some insect growth regulators on the cotton leafworm, Spodoptera littoralis (Boisd.). Ph. D. Thesis, Fac. Sci. Cairo Univ. Egypt. 
Anan, A. R.; Mona, I. M. and Nagwa, M. H. (1993). Biochemical effect of pyriproxyfen juvenoid on fat and haemolymph proteins of pink bollworm, Pectinophora gossypiella (Saund.) and spiny bollworm, Earias insulana (Boisd.). Ann. Agric. Sci., Ain Shams Univ., Egypt, 38: 761-72.

Assar, A. A.; Abo-El-Mahasen, M. M.; Harba, N. M. and Rady, A. A. (2012). Biochemical Effects of Cyromazine on Culex Pipiens Larvae (Diptera: Culicidae). J. Amer. Sci., 2012;8(5):443-450.

Assar, A. A.; Abo El-Mahasen, M. M.; Khalil, M. E.; and Mahmoud, S. H. (2010). Biochemical effects of some insect growth regulators on the house fly, Musca domestica (Diptera: Muscidae). Egypt. Acad. J. Biol. Sci., 2 (2): 33-44.

Azmi, M. A.; Sayed, N. H. and Khan, N. F. (1998). Comparative to biological studies of RB-a (Neem Extract) and Coopex (Permethrin + Bioallethrin) against Sitophilus oryzae with reference to their effects on ogxygen consumption and GOT and GPT activity. J. Zool., 22:307-310.

Bade, M. L. and Stinson, A. (1981). Biochemistry of insect differentiation. A system for studying the mechanism of chitinase activity in vitro. Archs. Biochem. Biophys., 206: $213-221$.

Bakr, R. F. (1986). Morphogenic and physiological aberration induced by certain IGRs in the house fly, Musca domestica. Ph. D. Thesis, Fac. Sci., Ain Shams Univ. Egypt.

Cheng, Y.; Sun, Y.; Xia, L.; Sun, B. and Mao, H. (2007). Evaluation of effect of the biocide and pesticide stemming from botany eliminating Locusta Migratoria manilensis Meyen. Chinese Agri. Sci. Bull., 23: 262-264.

El-Sheikh, T. A. (2002). Effects of application of selected insect growth regulators and plant extracts on some physiological aspects of the black cutworm, Agrotis ipsilon (Huf). Ph. D. thesis, Fac. Sci., Ain Shams Univ.

Farag, A. M. (2001). Biochemical studies on the effect of some insect growth regulators on the cotton leafworm. M. Sc. thesis Fac. Agric. Cairo Univ. Egypt.

Gatehouse, A. M. R; Norton, E.; Davison, G. M.; Babbe, S. M.; Newell, C. A. and Gatehouse, J. A. (1999). Digestive proteolytic activity in larvae of tomato moth, Lacanobia oleracea; Effects of plant protease inhibitors in vitro and in vivo. J. Ins. Physiol., 45: 545-558.

Gilbert, L. I. (1967): Lipid metabolism and function of insects. Adv. Ins. Physiol., 4: 69-211.

Gowda, V. T. and Ramaiah, T. R. (1976). Effect of induced poyhdrosis on haemolymph transaminases in the larvae of the silkworm Bombyx mori. J. Invert. Pathol., 28 (2): 271-72.

Hegazy, G. and Degheele, D. (1990). The ultrastructure of muscle attachment in larvae of Spodoptera littoralis with special reference to diflubenzuron treatment, Mededlingen Van de Faculteit Landbouww. Rijksuniv. Gent. Belgium., 55: 609-620.

Hunter-Jones, P. (1961). Rearing and breeding locusts in the laboratory. Bull. Anti-locust Res. Cent. Lond., 12 pp. 
Koul, O.; Shankar, J. S. and Kapil, S. (1996). Bioefficacy and mode-of-action of some limonoids of salannin group from Azadirachta indica A. Juss and their role in a multicomponent system against lepidopteran larvae Entamol. Exp. Appl., 79: 43 (1996).

Meister, A. (1957): Transamination advanced. Enzymol., 19:185-246.

Mordue, L. and Blackwell, A. (1993). Azadirachtin: An update. J. Ins. Physiol., 39: 903-924.

Mordue, W. and Goldworthy, G. J. (1973). Transaminase levels and uric acid production in adult locusts. Ins. Biochem., 3: 419-427.

Mostafa, S. A. (1993). Biochemical effects of some chemical compounds on Spodoptera littoralis (Boised.). Ph. D. Thesis, Fac. Agric., Al-Azhar Univ., Egypt.

Powell, M. E. A. and Smith, M. J. H. (1954). The determination of serum acid and alkaline phosphatase activity with 4-aminoantipyrine. J. Clin. Pathol., 7: 245-248.

Reitman, S. and Frankle, S. (1957). Colourimetric method for aspartate and alanine transaminases. Amer. J. Pathol., 28:56.

Reynolds, S. E. and Samuels, R. I. (1996). Physiology and biochemistry of insect moulting fluid. Adv. Ins. Physiol., 26, 157-232.

Roland, S. and Uwe, R. (2004). Juvenile hormone-dependent motor activation in the adult locust Locusta migratoria. J. Comp. Physiol. 190: 883-894.

Saha, L. M.; Mandal, S. and Choudhuri, D. K. (1986). The effect of juvenile hormone analogue and ecdysterone on the fat body of female Chrysocoris stolli Wolf (Pentatomidae: Heteroptera: Hemiptera). Zoologische Jahrbucher, Abteil. Allgem. Zool. Physiol. der Tiere., 90 (1): 85-100.

SAS Institute (1988). SAS/ STAT User's Guide, Ver. 6.03. SAS Institute Inc., Cary, North Carolina.

Sokar, L. A. (1995). Possible alternatives to classical insecticides in management program of Spodoptera littoralis (Boisd). Ph. D. Thesis, Zag. Univ., Egypt.

Sridhara, S. and Bhat, J. V. (1963). Alkaline and acid phosphatases of the silkworm, Bombyx mori L. J. Ins. Physiol., 9: 693-701.

Taha, G. Z. and El-Gammal, A. M. (1990). Morphogenetic effects of nonterpenoid juvenile hormone analogue. S-31183 on metamorphosis of last nymphal instar of Schistocerca gregaria. Egypt J. Appl. Sci., 5: 7581.

Timmins, W. A. and Reynolds, S. E. (1992). Azadirachtin inhibits secretion of trypsin in midgut of Manduca sexta caterpillars: reduced growth due to impaired protein digestion. Entomol. Exp. Appl., 63: 47-54.

Trumm, P. and Dorn, A. (2000). Effects of azadirachtin on the regulation of midgut peristalsis by the stomatogastric nervous system in Locusta migratoria. Phytoparasitica, 28 (1): 7-26. 
Tsumuki, H. and Kanehisa, K. (1984). Phosphatases in the rice stem borer, Chilo suppersdlis Walker (Lepidoptera: Pyralidae): Some properties and changes of the activities during hibernation. Cytobiol., 21: 177-82.

Wang, Y. and Wang, M. (2007). The research of IGRs. World Pestic., 29: 811.

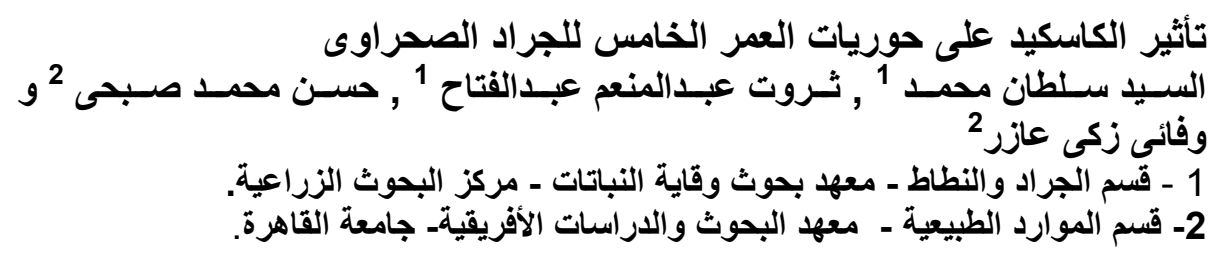

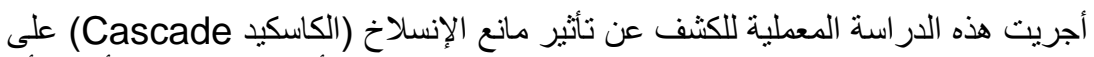

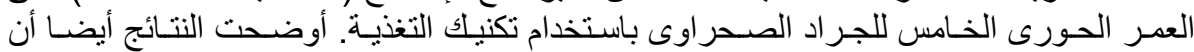

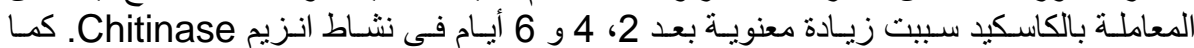

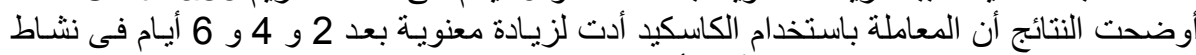

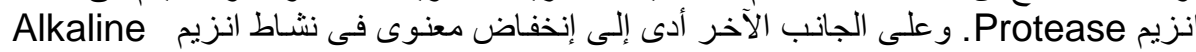
Phosphatase

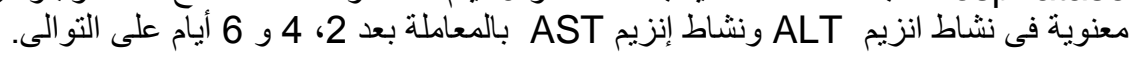

قام بتحكيم البحث

كلية الزراعة - جامعة المنصورة

أ.د / عبد البديع عبد الحميد غانم

كلية الزراعة - جامعة المنصورة

أ.د / هالة أحمد كامل الصرفى 